University of Nebraska - Lincoln

DigitalCommons@University of Nebraska - Lincoln

\title{
Examining career-related mentoring and managerial performance across cultures: A multilevel analysis
}

\author{
William A. Gentry \\ Center for Creative Leadership, Greensboro, NC, gentryb@leaders.ccl.org \\ Todd J. Weber \\ University of Nebraska at Lincoln, drawkcab321@gmail.com \\ Golnaz Sadri \\ California State University, Fullerton
}

Follow this and additional works at: https://digitalcommons.unl.edu/leadershipfacpub

Part of the Management Sciences and Quantitative Methods Commons

Gentry, William A.; Weber, Todd J.; and Sadri, Golnaz, "Examining career-related mentoring and managerial performance across cultures: A multilevel analysis" (2008). Leadership Institute Faculty Publications. 4. https://digitalcommons.unl.edu/leadershipfacpub/4

This Article is brought to you for free and open access by the Leadership Institute at DigitalCommons@University of Nebraska - Lincoln. It has been accepted for inclusion in Leadership Institute Faculty Publications by an authorized administrator of DigitalCommons@University of Nebraska - Lincoln. 
Published in Journal of Vocational Behavior 72 (2008), pp. 241-253; doi:10.1016/j.jvb.2007.10.014

Copyright (C) 2007 Elsevier Inc. Used by permission. http://www.elsevier.com/locate/jvb

The authors would like to express our appreciation to Ellen Van Velsor and Marian N. Ruderman for their insightful comments in reviewing earlier versions of this manuscript.

Submitted March 30, 2007; published online December 5, 2007.

\title{
Examining career-related mentoring and managerial performance across cultures: A multilevel analysis
}

\author{
William A. Gentry, ${ }^{1}$ Todd J. Weber, ${ }^{2}$ and Golnaz Sadri ${ }^{3}$ \\ ${ }^{1}$ Center for Creative Leadership, One Leadership Place, Research and Innovation, \\ Post Office Box 26300, Greensboro, NC 27438-6300, USA \\ 2 University of Nebraska-Lincoln, Gallup Leadership Institute, \\ 114 College of Business Administration, Lincoln, NE 68588-0497, USA \\ ${ }^{3}$ Management Department, College of Business and Economics, \\ California State University, Fullerton, PO Box 6848, Fullerton, CA 92834, USA \\ Corresponding author - W. A. Gentry, fax 336 286-4434, email gentryb@leaders.ccl.org
}

\begin{abstract}
The benefits of the mentoring relationship for protégés have been a primary focus in the mentoring literature. Researchers have recently begun to examine how mentoring can benefit the mentor. The purpose of the present study is to examine whether direct report-ratings of a manager's career-related mentoring behaviors are related to boss-ratings of that manager's performance. In addition, this study assesses whether the cultural background of the manager moderates the career-related mentoring-performance relationship via multilevel methodology. Results reveal that managers who are rated by their direct reports as engaging in career-related mentoring behaviors are perceived as better performers by their bosses. Moreover, the GLOBE societal culture dimension of Performance Orientation was a significant crosslevel moderator of the career-related mentoring-performance relationship. Implications for the practice of mentoring in cross-cultural contexts across multiple disciplines are discussed.
\end{abstract}

Keywords: career-related mentoring, culture, hierarchical linear modeling, GLOBE, leadership

\section{Introduction}

The concept of mentoring dates back to Homer's Odyssey where Odysseus, before leaving to fight in the Trojan war, entrusted his older friend Mentor to teach and educate his son, Telemachus. The term "mentor" has become proverbial for a faithful, trusted or wise advisor. Researchers have begun to study mentoring across various contexts and disciplines, including youth mentoring (DuBois \& Karcher, 2005; Linnehan, 2003; Miller, 2002; Rhodes \& Bogat, 2002) faculty-student mentoring (Busch, 1985; Campbell \& Campbell, 1997) and the workplace. 
The study of mentoring has expanded substantially since the works of Levinson, Darrow, Klein, Levinson, and McKee (1978) and Kram (1985), including: benefits of being mentored versus not being mentored; choice in the mentoring relationships; differences between formal and informal mentoring programs; motives and willingness to mentor; gender and race differences; and associations with objective and subjective career success (see Allen, Eby, Poteet, Lentz, \& Lima, 2004; Noe, Greenberger, \& Wang, 2002; Ragins \& Cotton, 1999; Underhill, 2006; Wanberg, Welsh, \& Hezlett, 2003 for reviews). Of particular interest to our study is career-related mentoring research in the managerial or supervisory domains (e.g., Scandura \& Williams, 2004; Sosik \& Godshalk, 2000; Sosik, Godshalk, \& Yammarino, 2004).

Mentoring research has shown that protégés receive substantial benefits including higher job performance ratings (Scandura \& Williams, 2004). There is, however, a growing interest in the benefits of mentoring to the mentor (Allen, 2007; Allen, Lentz, \& Day, 2006; Allen, Poteet, \& Burroughs, 1997; Eby, Durley, Evans, \& Ragins, 2006). In qualitative studies, mentors experience increased personal and job satisfaction (Allen et al., 1997; Kram, 1985; Levinson et al., 1978). Quantitatively, mentoring relates to a mentor's objective and subjective career success (Allen et al., 2006; Bozionelos, 2004), as well as job attitudes and reduced job content plateauing (Lentz \& Allen, in press). A shortcoming of the current mentoring literature is that personal factors (e.g., satisfaction) and indirect measures of success (e.g., higher incomes, faster promotion rates) are used as proxies for managerial or organizational performance, with a few exceptions (e.g., Eby et al., 2006). Moreover, very little cross-cultural mentoring research exists.

We extend mentoring research by investigating the benefits of career-related mentoring to the mentoring manager as well as examining how societal culture relates to the mentoring relationship. We first review existing mentoring research to identify why career-related mentoring should be linked to a manager's performance. We then examine the cultural dimension of "Performance Orientation" as a cross-level moderator and empirically test our hypotheses using hierarchical linear modeling (HLM). We also discuss the implications of our findings, including how our research may inform other mentoring contexts such as youth mentoring and faculty- student mentoring.

\subsection{Mentoring and manager performance}

Kram (1985), among others, theorized different mentoring functions and behaviors that aid in the growth, development, and advancement of others. Specifically, Kram argued that a mentor assists a protégé by providing career-related and psychosocial support (see Kram, 1985 for details of each mentoring function). Subsequent empirical and conceptual work has supported these mentoring functions (Allen et al., 2004). Our research focuses specifically on career-related mentoring (e.g., sponsorship, coaching, or challenging assignments).

Managers who mentor their direct reports affect significant outcomes for direct reports, including job performance, satisfaction, organizational commitment, and turnover intentions (e.g., Brashear, Bellenger, Boles, \& Barksdale, 2006; Raabe \& Beehr, 2003; Scandura \& Schriesheim, 1994; Scandura \& Williams, 2004; Sosik \& Godshalk, 2000). Managers may also benefit from mentoring others (Allen, 2007; Allen et al., 2006; Bozionelos, 2004; Eby et al., 2006). We contribute to mentoring research by examining the relationship between the use of career-related mentoring behaviors and ratings of performance for the mentoring manager.

There is evidence that those who mentor have higher job satisfaction and motivation, feel more satisfied and rejuvenated, gain a sense of accomplishment and meaning in work, and increase their esteem among peers and managers (Hunt \& Michael, 1983; Kram, 1985; Levinson et al., 1978; Ragins \& Scandura, 1999). Though not performance outcomes, these often are related to increased performance. Mentoring theory (Kram, 1985) suggests an additional benefit for managers in terms of performance; when a mentoring manager develops protégés and increasingly delegates work to them, managers may become more effective and efficient in their jobs (Nykodym, Freedman, Simonetti, \& Nielsen, 1995). Moreover, information and support from protégés may become the foundation for a mentoring manager's organizational advancement (Dreher \& Ash, 1990). Recently, Bozionelos (2004) found that the mentoring a manager provided was directly related to the manager's career success, demonstrating that a manager's career can be enhanced when the manager mentors others.

Mentoring may also benefit managers based on upward striving (Wollack, Goodale, Wijting, \& Smith, 1971). Managers generally desire to move up in an organization and better their standard of liv- 
ing. By mentoring direct reports, a manager may expand his or her power base and reputation by preparing them for additional positions of responsibility. Successful direct reports reflect highly on the mentoring manager, building the manager's reputation among higher management (Kram, 1985), facilitating the manager's own movement upward in the organization (Allen, Poteet, Russell, \& Dobbins, 1997; Hunt \& Michael, 1983).

In a more recent theoretical development, Ramaswami and Dreher (2007) noted that mentoring may enhance a mentor's own performance. Direct reports may "pay back" their mentoring managers by becoming an "informant", providing feedback about the manager's performance and supplying critical information about the environment to the mentoring manager. This is similar to social exchange theory and the norm of reciprocity (Blau, 1964; Eisenberger, Huntington, Hutchison, \& Sowa, 1986), where a manager mentors direct reports with the expectation that direct reports would "pay back" the mentoring manager at a future date, providing the manager with additional resources to help accomplish his or her work. The manager may form "mentoring networks", increasing his/her reputation and power. Managers who mentor direct reports may be seen by their own bosses and upper management as having good judgment, reputation and credibility, which may result in the manager's advancement, increased recognition, influence, clout, visibility, legitimacy, respect and admiration (Noe, 1988; Ragins, 1997; Ragins \& Scandura, 1994).

Mentoring takes time and an argument can be made for this being a distraction from activities more directly related to performance. However, managers are often dependent on the relationships they develop, and mentoring can be important for developing and motivating others. The perception of being an effective manager can be critical to job performance, and mentoring can be very helpful in shaping these perceptions. As a result of existing research and the theoretical lenses identified above, we hypothesize the following:

Hypothesis 1. Displays of career-related mentoring behaviors will be positively related to perceptions of managerial performance. Specifically, higher ratings of a manager displaying career-related mentoring behaviors will be related to higher performance ratings.

\subsection{Societal culture}

Societal culture research has increased in recent years, particularly through the use of cultural dimensions (Hofstede, 2001; Kirkman, Lowe, \& Gibson, 2006; Triandis, 2003). However, few studies in the mentoring literature have drawn from this work on societal culture. Although mentoring research has examined a number of important contextual variables such as race and gender (e.g., Kram, 1985; Noe et al., 2002; Ragins \& Cotton, 1999) little research exists examining societal culture's relationship with mentoring. Consequently, one cannot assume that research on mentoring relationships conducted in AngloSaxon environments generalize to other places such as Greece (Bozionelos, 2006) or China (Bozionelos \& Wang, 2006). The lack of cross-cultural generalizability has significant practical implications for expatriate managers and those who manage within culturally diverse home environments. Moreover, cross-cultural studies could provide valuable information for a wide range of mentoring relationships, such as youth mentoring or faculty-student mentoring.

Societal culture pertains to how a group of people organize and perceive the world (Hall, 1973). Alternatively referred to as national culture, societal culture seeks to simplify and describe the complex differences between groups in different parts of the world that have developed over time. Based in part on Hofstede's (1984) work, the GLOBE project identified nine cultural dimensions (see House, Hanges, Javidan, Dorfman, \& Gupta, 2004 for a detailed review). As with all major cross-cultural frameworks, this method of examining culture has generated some skepticism and debate (Earley, 2006; Hofstede, 2006; Javidan, House, Dorfman, Hanges, \& Sully de Luque, 2006; Smith, 2006). However, this approach seems promising on several conceptual and methodological levels. The GLOBE project is the most recent study of culture across societies, and addresses several of the conceptual and methodological limitations identified with the older cultural models (e.g., Hofstede, 1980; Schwartz, 1992; Trompenaars, 1994). In addition, the distinctions between values and behaviors, the explicit reference points, and the process by which GLOBE developed and validated its scales provide the flexibility, conceptual clarity, and psychometric properties needed for a cross-cultural study of mentoring. As a result we chose the GLOBE framework for our measure of societal values. 
Consistent with Parboteeah, Bronson, and Cullen (2005), we used a literature review with theoretical reasoning to identify "Performance Orientation" (PO) as a cultural variable that is relevant to career-related mentoring. In addition to being a conceptually relevant cultural dimension, the values underlying $\mathrm{PO}$ align coherently with the practice of mentoring. Below we define $\mathrm{PO}$ and hypothesize how it fits as a cultural variable to be examined in our study.

\subsubsection{Performance orientation}

Defined as "the degree to which an organization or society encourages and rewards group members for performance improvement and excellence" (House \& Javidan, 2004, p. 13), PO is based on McClelland's (1961) need for achievement. Javidan (2004, p. 277) explains that "[Performance Orientation] relates to the extent to which leaders set ambitious goals, communicate high expectations for their subordinates, build their subordinates' self-confidence, and intellectually challenge them". This definition aligns well with career-related mentoring functions, such as coaching or providing a challenging climate or assignment. Moreover, societies that score higher on PO tend to value training and development, expect demanding targets, believe that individuals are in control, value and reward individual performance and achievement, believe in direct and explicit communication, and view feedback as essential for improvement. In contrast, societies lower on PO view feedback and appraisal as judgmental and uncomfortable, preferring the use of indirect and subtle communication instead. High PO societies value initiative and action, believing success is available to all those who work hard and show diligence. Low PO societies link competition with defeat and punishment. Based on this discussion, one can see that the cultural goals of high PO cultures (e.g., value of training and development, feedback as essential) are congruent with mentoring practices while certain aspects in low PO cultures (e.g., feedback as judgmental and uncomfortable) are not. Given that the benefits of mentoring may be influenced by national cultural characteristics (Bozionelos, 2006), we believe there is alignment between mentoring and the value high PO cultures place on development, challenge, and feedback.

Hypothesis 2. PO will be a cross-level moderator. Specifically, the relationship between career mentoring behaviors and performance will be stronger in high PO cultures than it will in low PO cultures.

\section{Methods}

\subsection{Participants and procedures}

We used a sample of 30,365 practicing managers from 33 different countries in over 4000 different companies headquartered around the world. Table 1 lists the number of managers per country. The final sample of practicing managers was based on: (a) managers currently working in their country of origin; (b) usable and complete multisource data of at least 20 managers per country; and (c) the country being part of the GLOBE study. Managers varied in terms of age, gender, organization and job tenure, and organization level (see Table 2). Variables such as education, ethnicity/race and compensation were not available for this study, due either to countries limiting the collection of this type of information or to items being US-centric and not applicable to an international sample.

\subsection{Measures}

\subsubsection{Performance}

Existing managerial performance data from each manager's organization was not available. To attain a measure of performance, the boss of each target-manager rated each target-manager on a 5-point, Likert-type response format on three separate questions: (a) participant's performance in his/her present job $(1=$ among the worst to $5=$ among the best $)(M=4.19, S D=.85)$; (b) participant's performance as a leader compared to other leaders inside and outside of the organization $(1=$ among the worst to $5=$ among the best) $(M=3.83, S D=.92)$; and (c) participant's likelihood of derailment in the next 5 years $(1$ $=$ not at all likely to $5=$ almost certain; reversed) (reversed $M=4.23, S D=.93$ ). Consistent with past re- 
Table 1. Number of managers within countries studied and "Performance Orientation" score

\begin{tabular}{|c|c|c|}
\hline Country & $n$ & GLOBE score \\
\hline Argentina & 41 & 6.35 \\
\hline Australia & 234 & 5.89 \\
\hline Brazil & 80 & 6.13 \\
\hline Canada & 1,055 & 6.15 \\
\hline China & 62 & 5.67 \\
\hline Denmark & 55 & 5.61 \\
\hline Finland & 33 & 6.11 \\
\hline France & 218 & 5.65 \\
\hline Germany & 223 & 6.01 \\
\hline Greece & 22 & 5.81 \\
\hline Hong Kong & 38 & 5.64 \\
\hline India & 127 & 6.05 \\
\hline Indonesia & 81 & 5.73 \\
\hline Ireland & 127 & 5.98 \\
\hline Italy & 65 & 6.07 \\
\hline Japan & 54 & 5.17 \\
\hline Malaysia & 33 & 6.04 \\
\hline Mexico & 123 & 6.16 \\
\hline Netherlands & 253 & 5.49 \\
\hline New Zealand & 157 & 5.90 \\
\hline Philippines & 53 & 6.31 \\
\hline Poland & 44 & 6.12 \\
\hline Portugal & 31 & 6.40 \\
\hline Singapore & 335 & 5.72 \\
\hline South Korea & 55 & 5.25 \\
\hline Spain & 171 & 5.80 \\
\hline Sweden & 75 & 5.80 \\
\hline Switzerland & 87 & 5.82 \\
\hline Thailand & 32 & 5.74 \\
\hline Turkey & 54 & 5.39 \\
\hline United Kingdom & 796 & 5.90 \\
\hline United States & 25,529 & 6.14 \\
\hline Venezuela & 22 & 6.35 \\
\hline
\end{tabular}

GLOBE scores are “Performance Orientation” values from Javidan (2004), p. 251.

Table 2. Means, standard deviations, and intercorrelations among level 1 variables

\begin{tabular}{|c|c|c|c|c|c|c|c|c|c|c|}
\hline Variable & $M$ & $S D$ & 1 & 2 & 3 & 4 & 5 & 6 & 7 & 8 \\
\hline 1. Age & 42.80 & 7.19 & - & & & & & & & \\
\hline 2. Gender ${ }^{a}$ & 0.33 & .47 & -.03 & - & & & & & & \\
\hline 3. Managerial level ${ }^{\mathrm{b}}$ & 2.03 & .89 & .16 & -.07 & - & & & & & \\
\hline 4. Job tenure & 4.16 & 4.73 & .23 & .00 & .01 & - & & & & \\
\hline 5. Organization tenure & 11.06 & 8.18 & .39 & -.03 & -.04 & .25 & - & & & \\
\hline 6. Organization type ${ }^{c}$ & NA & NA & .16 & .15 & -.09 & .07 & .11 & - & & \\
\hline 7. Career mentoring & 3.81 & .53 & .02 & .10 & -.01 & .00 & .06 & .07 & - & \\
\hline 8. Performance & 0.06 & 2.53 & -.10 & .04 & .02 & -.03 & .02 & .08 & .24 & - \\
\hline
\end{tabular}

All correlations greater or equal to $|.02|$ are significant at $p<.01$.

a $0=$ Male, $1=$ Female.

$\mathrm{b}_{0}=$ First-level, 1 = Middle-level, 2 = Upper-Middle-level, 3 = Executive, 4 = Top.

${ }^{\mathrm{c}}$ Nonsense coding was used: 0 = Business: Other, 1 = Military, 2 = Business: Manufacturing, 3 = Business: Finance, Insurance, Banking, 4 = Business: Health, 5 = Business: Transportation, Communication, Utilities, $6=$ Business: Wholesale/Retail Trade, $7=$ Private Nonprofit, $8=$ Public. Job and Organization tenure measured in years.

search that used the same performance questions (e.g., Graves, Ohlott, \& Ruderman, 2007; Van Velsor, Taylor, \& Leslie, 1993), we standardized these items (to account for differences in the response scale) 
and added these three items together to form a boss-rating of managerial performance $(\mathrm{a}=.81$ for the present study). We also followed previous research suggesting boss-ratings to be the most common and reliable way to measure performance of a target-manager (Conway, 2000; Conway \& Huffcutt, 1997; Viswesvaran, Ones, \& Schmidt, 1996). As part of the survey, respondents were notified that the performance questions were for research purposes only and that no feedback would be given to the targetmanager for these questions.

\subsubsection{Career mentoring behaviors}

A multisource developmental feedback instrument called BENCHMARKS ${ }^{\circledR 1}$ (Lombardo \& McCauley, 1994; Lombardo, McCauley, McDonald-Mann, \& Leslie, 1999; McCauley \& Lombardo, 1990) gathered ratings from the self- and multiple observer perspectives. We used direct-report ratings because (a) the most meaningful data in terms of behavior is from the perspective of followers or direct reports (Ashford, 1989; Atwater \& Yammarino, 1992; Bass, 1990); and (b) the purpose of this study was to examine how direct reports viewed the career-related mentoring behaviors of their manager. Direct reports of each target-manager rated the extent to which the target-manager displayed career-related mentoring behaviors on a 5point Likert-type scale $(1=$ not at all to $5=$ to a very great extent $)$. Data from direct reports were aggregated and given back to the target-managers anonymously.

Although validated measures of career-related mentoring constructs exist, such measures were not part of this database. As a result, we created a measure of career-related mentoring from the existing 115 items of Section 1 of BENCHMARKS ${ }^{\circledR}$ that were conceptually linked with career-related mentoring concepts to make a short scale of career-related mentoring. We first reviewed all of the BENCHMARKS ${ }^{\circledR}$ items to identify those that were related to the concept of career-related mentoring, resulting in 13 relevant items of career-related support functions. To assess content validity, an initial pool of items was then developed for each career-related support function consisting of the items we had selected as well as items from published measures of career-related support (see Appendix of Ragins \& Cotton, 1999). A descriptive statement for each function was listed with instructions to rate how well the items mapped onto a specific career-related mentoring function using a 7 -point scale $(1=$ very inconsistent, $7=$ very consistent). Nineteen individuals with advanced degrees in I-O psychology and closely related fields rated each item. We used $r_{\mathrm{wg}(j)}$ (James, Demaree, \& Wolf, 1984) to select items with a high level of interrater agreement $\left(r_{\mathrm{wg}(j)}>.70\right)$ and with a high level of consistency with the descriptive statement $(\geq 6$ on the 7 -point scale). The six items that were identified through this process were used as our measure of career-related mentoring behaviors. This content analysis process showed a strong conceptual overlap between the items in BENCHMARKS ${ }^{\circledR}$ and existing measures of career-related support functions existing in the mentoring literature.

Scale reliabilities were calculated to ensure the six items performed with adequate reliability $(\alpha=.88$ for the present study). In addition, we tested for construct uniformity by conducting a principal axis exploratory factor analysis using the "eigenvalue greater than 1" rule-of-thumb which generated one factor explaining over $63 \%$ of the variance. Item loadings ranged from .65 and .81. Example items include "Actively promotes his/her direct reports to senior management" and "Sets a challenging climate to encourage individual growth".

To facilitate our analysis of this dataset, we used all six items as a formative measure of career-related mentoring. Though not as clean or advantageous as distinct measures for each career-related function, it is consistent with current mentoring research and theory, which argues that mentoring does not require all support functions for mentoring to occur. Mentoring is not an "all or nothing" experience and frequently has a select number of career-related functions at a given time (Bozionelos, 2004; Kram, 1985; Ragins, Cotton, \& Miller, 2000). Our approach is in line with Bozionelos' suggestion that "a scale that taps the extent to which the individual has provided a variety of mentoring functions, for one or more subordinates [direct reports], should be apt at capturing individual variability in experience in providing mentoring" (2004, p. 34).

1. BENCHMARKS ${ }^{\circledR}$ is a registered trademark of the Center for Creative Leadership. 


\subsubsection{Performance orientation}

We used the published country scores (see Table 1) from GLOBE as our measure of PO. We opted to use the societal values scores (how things should be) rather than the societal practice scores (how things are) as it best reflected the cultural values and preferences (see House et al., 2004, for description of scale development).

\subsubsection{Control variables}

Gender, age, and the human capital variables of job and organization tenure were included as control variables since these variables can account for variance in performance outcomes (Judge, Cable, Boudreau, \& Bretz, 1995; Judiesch \& Lyness, 1999; Ng, Eby, Sorensen, \& Feldman, 2005). We also controlled for managerial level and organization type because the managers in our study worked across different levels and a variety of organizations.

\subsection{Analytic approach}

With managers nested within a country (culture), the multilevel nature of our data suggests HLM as the most appropriate analytic technique (Raudenbush \& Bryk, 2002). Traditional ordinary-least-squares (OLS) regression methods would neglect such a nested relationship. Our hypotheses suggest a conceptual model covering two levels of analysis. Hypothesis 1 is a Level-One model (two individual-level variables) while Hypothesis 2 is a Level-Two model (the published PO societal value score as a "Level-Two" variable). Information about HLM can be found elsewhere (e.g., Hofmann, 1997; Raudenbush \& Bryk, 2002). We used the HLM 6 software (Raudenbush, Bryk, \& Congdon, 2004) for our analyses.

\section{Results}

\subsection{Aggregation issues}

An average of 3.67 direct reports (range 2-22) rated each target-manager on career-related mentoring behaviors. We calculated $r_{\mathrm{wg}(j)}$ (James et al., 1984) for within-group homogeneity for each target-manager rated $\left(r_{\mathrm{wg}(j)}>.70\right.$; average $\left.=.92\right)$. We also calculated ICC $(2)$ to provide an estimate of the reliability of the group means (.65 for the present study) which was similar to other studies using similar multisource data (e.g., Graves et al., 2007). These results support aggregation of direct-report ratings.

Table 3. Hierarchical linear modeling models and results

\begin{tabular}{|c|c|c|c|c|}
\hline \multirow[t]{2}{*}{ Variable } & \multirow{2}{*}{$\begin{array}{l}\text { Hypothesis } 1 \\
r_{\mathrm{x} 0}\end{array}$} & \multicolumn{3}{|c|}{ Hypothesis 2} \\
\hline & & $r_{\mathrm{x} 0}$ & $r_{01}$ & $r_{71}$ \\
\hline Intercept & $-0.211^{*}$ & $-0.230^{*}$ & & \\
\hline Age & $-0.058^{* *}$ & $-0.057^{* *}$ & & \\
\hline Gender $^{\mathrm{a}}$ & $0.071^{*}$ & $0.074^{*}$ & & \\
\hline Managerial level ${ }^{\mathrm{b}}$ & $0.184^{* *}$ & $0.170^{* *}$ & & \\
\hline Job tenure & -0.008 & -0.008 & & \\
\hline Organization tenure & $0.021^{* *}$ & $0.021^{* *}$ & & \\
\hline Organization type ${ }^{\mathrm{c}}$ & 0.013 & 0.018 & & \\
\hline Career mentoring & $0.874^{* *}$ & $0.850^{* *}$ & & \\
\hline "Performance Orientation" & & & 0.064 & $0.911^{* *}$ \\
\hline
\end{tabular}

Hypothesis 1 = Random coefficient model; Hypothesis 2 = Slopes-as-outcomes.

All coefficients rounded to three decimal places.

a $0=$ Male, $1=$ Female.

b 0 = First-level, 1 = Middle-level, 2 = Upper-Middle-level, 3 = Executive, 4 = Top.

${ }^{c}$ Nonsense coding was used: 0 = Business: Other, 1 = Military, 2 = Business: Manufacturing, 3 = Business: Finance, Insurance, Banking, $4=$ Business: Health, $5=$ Business: Transportation, Communication, Utilities, $6=$ Business: Wholesale/Retail Trade, 7 = Private Nonprofit, $8=$ Public. Age, Job and Organization tenure measured in years.

${ }^{*} p<.05 ;{ }^{* *} p<.01$ 


\subsection{One-way ANOVA (null) model}

Table 2 provides means, standard deviations, and intercorrelation matrix of the Level-One (individual level) variables only. The first HLM model is a One-way ANOVA (null) model with no predictors and boss-ratings of target-manager performance as the outcome variable. The chi-square test $\left[\chi^{2}(32)=90.45, p\right.$ $<.01$ ] revealed statistically significant variation. Rejecting the null assumes that all countries statistically do not have similar ratings in performance, which permitted us to pursue our hypotheses. The Intraclass Correlation Coefficient (ICC; the percentage of variance in performance that exists between countries) was approximately $1 \%$.

\subsection{Random coefficient model - Test of Hypothesis 1}

The "Random-Coefficient" model tests Hypothesis 1, whether direct report-ratings of career-related mentoring behaviors relate to boss-ratings of performance. A "zero" was meaningful for job and organizational tenure in the context of the present study and the measures were not centered prior to placement in the equations. Organization type used nonsense coding, so it also was not centered. However, age, gender, organizational level, and direct-report ratings of career-related mentoring behaviors were centered around its respective group mean for meaningful interpretation. The $t$-test for $\gamma_{70}\left[\gamma_{70}=.874, t(32)=11.84\right.$, $p<.01]$ revealed that direct-report ratings of career-related mentoring behaviors of target-managers are positively related to boss-ratings of target-managers' performance, supporting Hypothesis 1 (see Table 3).

\subsection{Slopes-as-outcomes models - Tests of level 2 moderating hypotheses}

The next model tests Hypotheses 2, whether PO was a cross-level moderator. The $t$-test $\left[\gamma_{71}=.911, t(31)\right.$ $=5.88, p<.01]$ is statistically significant. $\mathrm{PO}$ as a Level-Two cultural variable was a cross-level moderator, supporting Hypothesis 2. Figure 1 shows the relationship using the value of the lowest-scoring country on PO (Japan) and the highest-scoring country (Portugal).

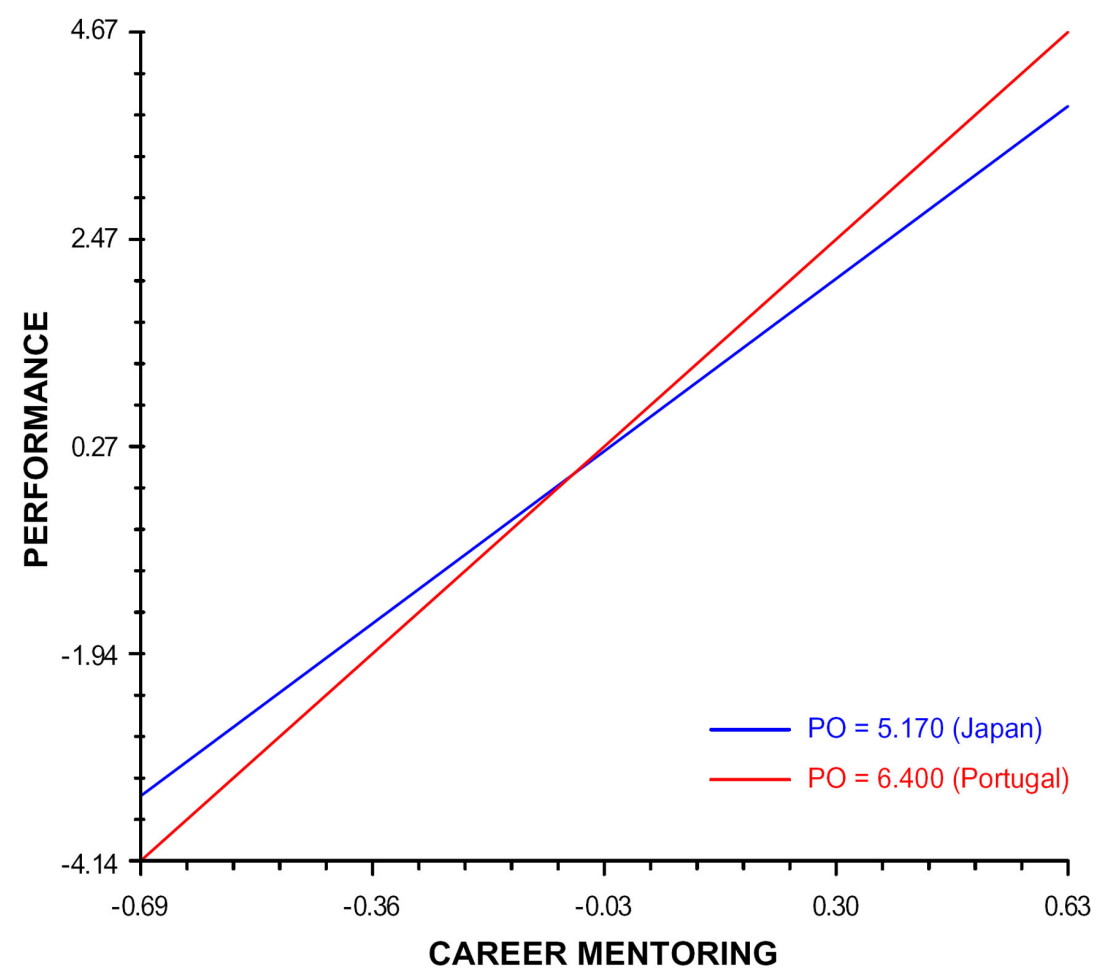

Figure 1. The moderating effects of power distance on the relationship between career mentoring and performance using lowest (Japan) and highest (Portugal) "Performance Orientation" countries. 


\section{Discussion}

This study builds upon the developing stream of research examining the positive outcomes received by the mentoring manager. We found direct report-ratings of their manager's career-related mentoring behaviors to be positively related to boss-ratings of the target-manager's performance when tested across a large international sample supporting Hypothesis 1.

A second contribution of this paper is the relationship between societal culture and mentoring. Our findings showed that PO was a cross-level moderator, supporting Hypothesis 2. Javidan (2004) suggests that cultures high in PO value training and development, and see feedback as essential and necessary for improving performance. Mentoring is a relationship that focuses on collaboration, development, and feedback. Our results suggest that cultures placing a high value on PO view mentoring as a beneficial relationship between a manager and his/her direct reports, and that mentoring is positively related to bossratings of managerial performance.

\subsection{Implications for practice}

Our findings have implications for the practice of management, particularly for expatriate managers being sent from low to high PO cultures. Societies scoring higher on PO emphasize results more than people (House et al., 2004), though such cultures do place a high focus on developing people in ways that will enhance their performance. Our results align with this focus on developing for performance. We suspect that mentoring others helps the mentoring manager build a range of communication and interpersonal skills such as the ability to develop others, communicate with others, and give feedback. Prior research suggests that diversity in mentoring relationships can increase the mentoring manager's understanding of others (Ragins, 1997; Schulz, 1995) which is likely to lead to improved job performance for the mentoring manager (Ramaswami \& Dreher, 2007). Thus, we suggest that the higher boss-ratings of managerial performance observed in this study are due, in part, to the development of important managerial skills on the part of the mentoring manager.

\subsubsection{Implications for different mentoring contexts}

Mentoring is a multi-disciplinary concept. One area of substantial interest is youth mentoring, estimated to involve approximately five million youth in some form of structured or unstructured school- or community-based volunteer mentoring programs in the USA (Rhodes, 2001). Though positive outcomes are associated with youth mentoring (e.g., Davidson \& Redner, 1998; Grossman \& Tierney, 1998; LoSciuto, Rajala, Townsend, \& Taylor, 1996), Rhodes suggests that over $50 \%$ of youth mentoring programs do not provide adequate training to their volunteer mentors. Attracting and retaining youth mentors is often difficult and training is a high priority. We suggest that success in recruiting youth mentors may increase when mentoring is shown to build the communication and interpersonal skills of the mentor. These improved skills are likely to benefit the mentor in a range of different occupations and contexts in the future. While it is unknown if our findings would generalize to youth populations, the findings suggest the need to be mindful of the way cultural context may influence the need for youth mentors. To this end, communicating the benefits of mentoring for mentors in general, and particularly in high PO cultures, becomes especially pertinent.

Similar to a managerial context, mentoring is also seen as an important skill for faculty in student-faculty relationships (Bigelow \& Johnson, 2001; Pfund, Pribbenow, Branchaw, Lauffer, \& Handelsman, 2006). To the extent that the two contexts have similar dynamics, our findings would imply that faculty displaying career-related mentoring behaviors in high PO cultures are more likely to be viewed as better performers as a result of their mentoring behaviors than faculty mentors in low PO cultures. Future research is needed to confirm whether these findings can be generalized to the student-faculty context. A similar pattern may apply to many types of hierarchical relationships that occur within a cross-cultural (or ethnically diverse) environment (e.g., residency/teacher training, clinical supervision). Those in a position to mentor may be seen as better performers and indeed, are likely to become better performers (e.g., as a teacher, trainer, mentor, etc.) through the development of various communication and interpersonal skills when they engage in mentoring behaviors. Our findings suggest that the relationship between mentoring and performance is particularly important in high PO cultures. Future research should explore the benefits of mentoring cross-culturally outside of the managerial context. 


\subsection{Strengths, limitations and future research}

Our study has several strengths including a substantial body of multisource data on practicing managers working in a range of companies worldwide. In addition, managers nested within a country allowed us to appropriately use HLM to account for the inherent nested relationship. A major contribution of our research is the expansion of mentoring research into the cross-cultural realm as well as a clear articulation of the relevance of multilevel analysis for this work. However, our research should be treated as a limited first step into this type of analysis. Given that the minimum data collection requirements to enable crosscultural multilevel analysis to occur are substantial, our study is likely to be of interest to the mentoring and cross-cultural literature despite its limitations. Minimally, our findings may inform those considering cross-cultural research by helping them set up data collection expectations properly.

There are also a number of limitations associated with our study. First, we assigned country scores from PO based on country of origin, implicitly assuming cultural boundaries were country boundaries. While this is a common practice in the cross-cultural literature, we recognize that it fails to take into account any within-country differences due to subcultures within a given country. Future research might consider within- and between-country differences. In a related matter, we did not directly measure the cultural values of the managers of our study and could not take into account the demographics of the raters of each manager. Future research might include primary measures of cultural values and rater demographics. We also focused solely on the culture dimension of performance orientation, rather than examining a range of cultural dimensions simultaneously. While focusing on a single dimension was important for theoretical and conceptual clarity, examining cultural values independently fails to take into account the interplay of the multiple layers that make up a culture and may give an incomplete picture of the relationship between cultural values and outcomes.

Some may view our findings as statistically significant but not practically significant given the small ICC across countries in the HLM ANOVA model. Managers in our study seemed to be "high performers"; managerial performance ratings were high based on the responses to the performance questions before standardization, which may bias results. This compressed variance is an unfortunate result of using an existing database where we did not have control over the performance measures that were used. Despite the sample being skewed in terms of high performance, culture was still related to the career-related mentoring-performance relationship.

Finally, our study is based exclusively on survey data from an existing multisource instrument designed for the development of practicing managers. Data was gathered concurrently for each participant, and, as a result, we are unable to infer causal relationships. Though better than self-report, ratings from the direct report-perspective may not be entirely valid. Future research should use longitudinal designs to determine whether previous mentoring behaviors predict future performance in order to identify causal relationships. In addition, our study did not specifically test the construct validity of our career-related mentoring measure. Future research might incorporate existing mentoring measures, using multiple sources of data, both quantitative and qualitative. Though our connections between mentoring and performance are theoretically based (e.g., Bozionelos, 2004; Kram, 1985; Ramaswami \& Dreher, 2007), we were not able to test the actual linkage. For instance, Ramaswami and Dreher (2007) propose that mentoring affects performance through an awareness of feedback, information, and the political climate. Future research would need to test these connections, particularly across cultures.

\section{References}

Allen, T. D. (2007). Mentoring relationships from the perspective of the mentor. In B. R. Ragins \& K. Kram (Eds.), The handbook of mentoring at work: Theory, research and practice (pp. 123-147). Thousand Oaks, CA: Sage.

Allen, T. D., Eby, L. T., Poteet, M. L., Lentz, E., \& Lima, L. (2004). Career benefits associated with mentoring for protégés: A meta-analysis. Journal of Applied Psychology, 89, 127-136.

Allen, T. D., Lentz, E., \& Day, R. (2006). Career success outcomes associated with mentoring others: A comparison of mentors and nonmentors. Journal of Career Development, 32, 272-285.

Allen, T. D., Poteet, M. L., \& Burroughs, S. M. (1997). The mentor's perspective: A qualitative inquiry and future research agenda. Journal of Vocational Behavior, 51, 70-89. 
Allen, T. D., Poteet, M. L., Russell, J. E. A., \& Dobbins, G. H. (1997). A field study of factors related to supervisors' willingness to mentor others. Journal of Vocational Behavior, 50, 1-22.

Ashford, S. J. (1989). Self-assessments in organizations: A literature review and integrative model. In L. L. Cummings \& B. M. Staw (Eds.). Research in organizational behavior (Vol. 11, pp. 133-174). Greenwich, CT: JAI Press.

Atwater, L. E., \& Yammarino, F. J. (1992). Does self-other agreement on leadership perceptions moderate the validity of leadership and performance predictions?. Personnel Psychology 45, 141-164.

Bass, B. M. (1990). Bass and Stogdill's handbook of leadership: Theory, research, and managerial applications (3rd ed.). New York: Free Press.

Bigelow, J. R., \& Johnson, W. B. (2001). Promoting mentor-protégé relationship formation in graduate school. Clinical Supervisor, 20(1), 1-23.

Blau, P. M. (1964). Exchange and power in social life. New York: Wiley.

Bozionelos, N. (2004). Mentoring provided: Relation to mentor's career success, personality, and mentoring received. Journal of Vocational Behavior, 64, 24-46.

Bozionelos, N. (2006). Mentoring and expressive network resources: Their relationship with career success and emotional exhaustion among Hellenes employees involved in emotion work. International Journal of Human Resource Management, 17, 362-378.

Bozionelos, N., \&Wang, L. (2006). The relationship of mentoring and network resources with career success in the Chinese organizational environment. International Journal of Human Resource Management, 17, 1531-1546.

Brashear, T. G., Bellenger, D. N., Boles, J. S., \& Barksdale, H. C. Jr., (2006). An exploratory study of the relative effectiveness of different types of sales force mentors. Journal of Personal Selling E Sales Management, 26(1), 7-18.

Busch, J. W. (1985). Mentoring in graduate schools of education: Mentors' perceptions. American Educational Research Journal, 22, 257-265.

Campbell, T. A., \& Campbell, D. E. (1997). Faculty/student mentor program: Effects on academic performance and retention. Research in Higher Education, 38, 727-742.

Conway, J. M. (2000). Managerial performance development constructs and personality correlates. Human Performance, 13, 23-46.

Conway, J. M., \& Huffcutt, A. I. (1997). Psychometric properties of multi-source performance ratings: A meta-analysis of subordinate, supervisor, peer, and self-ratings. Human Performance, 10, 331-360.

Davidson, W. S., \& Redner, R. (1998). The prevention of juvenile delinquency: Diversion from the juvenile justice system. In R. H. Price, E. L. Cowen, R. P. Lorion, \& J. Ramos-McKay (Eds.), Fourteen ounces of prevention: Theory, research, and prevention (pp. 123-137). New York: Pergamon.

Dreher, G. F., \& Ash, R. A. (1990). A comparative study of mentoring among men and women in managerial, professional, and technical positions. Journal of Applied Psychology, 75, 539-546.

DuBois, D. L., \& Karcher, M. J. (Eds.). (2005). Handbook of youth mentoring. Thousand Oaks, CA: Sage Publications, Inc..

Earley, P. C. (2006). Leading cultural research in the future: A matter of paradigms and taste. Journal of International Business Studies, 37, 922-931.

Eby, L. T., Durley, J., Evans, S. C., \& Ragins, B. R. (2006). The relationship between short-term mentoring benefits and long-term mentor outcomes. Journal of Vocational Behavior, 69, 424-444.

Eisenberger, R., Huntington, R., Hutchison, S., \& Sowa, D. (1986). Perceived organizational support. Journal of Applied Psychology, 71, 500-507.

Graves, L. M., Ohlott, P. J., \& Ruderman, M. N. (2007). Commitment to family roles: Effects on managers' attitudes and performance. Journal of Applied Psychology, 92, 44-56.

Grossman, J. P., \& Tierney, J. P. (1998). Does mentoring work? An impact study of the Big Brothers/Big Sisters program. Evaluation Review, 22, 403-426.

Hall, E. T. (1973). The silent language. New York: Anchor/Doubleday.

Hofmann, D. A. (1997). An overview of the logic and rationale of hierarchical linear models. Journal of Management, $23,723-744$.

Hofstede, G. (1980). Culture's consequences: International differences in work-related values. Beverly Hills, CA: Sage.

Hofstede, G. (1984). Culture's consequences. Thousand Oaks, CA: Sage Publications.

Hofstede, G. (2001). Culture's consequences: Comparing values, behaviors, institutions, and organizations across nations (2nd ed.). Thousand Oaks, CA: Sage Publications.

Hofstede, G. (2006). What did GLOBE really measure? Researchers' minds versus respondents' minds. Journal of International Business Studies, 37, 882-896. 
House, R. J., Hanges, P. J., Javidan, M., Dorfman, P. W., \& Gupta, V. (2004). Culture, leadership, and organizations: The GLOBE study of 62 societies. Thousand Oaks, CA: Sage Publications.

House, R. J., \& Javidan, M. (2004). Overview of GLOBE. In R. J. House, P. J. Hanges, M. Javidan, P. W. Dorfman, \& V. Gupta (Eds.), Culture, leadership, and organizations: The GLOBE study of 62 societies (pp. 9-28). Thousand Oaks, CA: Sage Publications.

Hunt, D. M., \& Michael, C. (1983). Mentorship: A career training and development tool. Academy of Management Review, 8, 475-485.

James, L. R., Demaree, R. G., \& Wolf, G. (1984). Estimating within-group interrater reliability with and without response bias. Journal of Applied Psychology, 69, 85-98.

Javidan, M. (2004). Performance orientation. In R. J. House, P. J. Hanges, M. Javidan, P. W. Dorfman, \& V. Gupta (Eds.), Culture, leadership, and organizations: The GLOBE study of 62 societies (pp. 239-281). Thousand Oaks, CA: Sage Publications.

Javidan, M., House, R. J., Dorfman, P. W., Hanges, P. J., \& Sully de Luque, M. (2006). Conceptualizing and measuring cultures and their consequences: A comparative review of GLOBE's and Hofstede's approaches. Journal of International Business Studies, 37, 897-914.

Judge, T. A., Cable, D. M., Boudreau, J. W., \& Bretz, R. D. (1995). An empirical investigation of the predictors of executive career success. Personnel Psychology, 48, 485-519.

Judiesch, M. K., \& Lyness, K. S. (1999). Left behind? The impact of leaves of absence on managers' career success. Academy of Management Journal, 42, 641-651.

Kirkman, B. L., Lowe, K. B., \& Gibson, C. B. (2006). A quarter century of Culture's consequences: A review of empirical research incorporating Hofstede's cultural values framework. Journal of International Business Studies, 37 , 285-320.

Kram, K. E. (1985). Mentoring at work. Glenview, IL: Scott, Foresman, and Company.

Lentz, E., \& Allen, T. D. (in press). The link between mentoring and the career plateau-addressing the empirical gap. Group \& Organization Management.

Levinson, D. J., Darrow, C. N., Klein, E. B., Levinson, M. H., \& McKee, B. (1978). Seasons of a man's life. New York: Knopf.

Linnehan, F. (2003). A longitudinal study of work-based, adult-youth mentoring. Journal of Vocational Behavior, 63(1), 40-54.

Lombardo, M. M., \& McCauley, C. D. (1994). BENCHMARKS ${ }^{\circledR}:$ A manual and trainer's guide. Greensboro, NC: Center for Creative Leadership.

Lombardo, M. M., McCauley, C. D., McDonald-Mann, D., \& Leslie, J. B. (1999). BENCHMARKS ${ }^{\circledR}$ developmental reference points. Greensboro, NC: Center for Creative Leadership.

LoSciuto, L., Rajala, A. K., Townsend, T. N., \& Taylor, A. S. (1996). An outcome evaluation of across Ages: An intergenerational mentoring approach to drug prevention. Journal of Adolescent Research, 11, 116-129.

McCauley, C., \& Lombardo, M. (1990). BENCHMARKS ${ }^{\circledR}$ : An instrument for diagnosing managerial strengths and weaknesses. In K. E. Clark \& M. B. Clark (Eds.), Measures of leadership (pp. 535-545). West Orange, NJ: Leadership Library of America.

McClelland, D. C. (1961). The achieving society. Princeton, NJ: Van Nostrand.

Miller, A. (2002). Mentoring students E young people: A handbook of effective practice. London: Kogan Page.

Ng, T. W. H., Eby, L. T., Sorensen, K. L., \& Feldman, D. C. (2005). Predictors of objective and subjective career success: A meta-analysis. Personnel Psychology, 58, 367-408.

Noe, R. A. (1988). An investigation of the determinants of successful assigned mentoring relationships. Personnel Psychology, 41, 457-479.

Noe, R. A., Greenberger, D. B., \& Wang, S. (2002). Mentoring: What we know and where we might go. In G. R. Ferris \& J. J. Martocchio (Eds.). Research in personnel and human resources management (Vol. 21, pp. 129-173). Oxford: Elsevier.

Nykodym, N., Freedman, L. D., Simonetti, J. L., \& Nielsen, W. R. (1995). Mentoring: Using transactional analysis to help organizational members use their energy in more productive ways. Transactional Analysis Journal, 25, 170-179.

Parboteeah, K. P., Bronson, J. W., \& Cullen, J. B. (2005). Does national culture affect willingness to justify ethically suspect behaviors?: A focus on the GLOBE national culture scheme. International Journal of Cross Cultural Management, 5, 123-138.

Pfund, C., Pribbenow, C. M., Branchaw, J., Lauffer, S. M., \& Handelsman, J. (2006). The merits of training mentors. Science, 311(5760), 473-474. 
Raabe, B., \& Beehr, T. A. (2003). Formal mentoring, versus supervisor and coworker relationships: Differences in perceptions and impact. Journal of Organizational Behavior, 24, 271-293.

Ragins, B. R. (1997). Diversified mentoring relationships in organizations: A power perspective. Academy of Management Review, 22, 482-521.

Ragins, B. R., \& Cotton, J. L. (1999). Mentor functions and outcomes: A comparison of men and women in formal and informal mentoring relationships. Journal of Applied Psychology, 84, 529-550.

Ragins, B. R., Cotton, J. L., \&Miller, J. S. (2000). Marginal mentoring: The effects of type of mentor, quality of relationship, and program design on work and career attitudes. Academy of Management Journal, 43, 1177-1194.

Ragins, B. R., \& Scandura, T. A. (1994). Gender differences in expected outcomes of mentoring relationships. Academy of Management Journal, 37, 957-971.

Ragins, B. R., \& Scandura, T. A. (1999). Burden of blessing? Expected costs and benefits of being a mentor. Journal of Organizational Behavior, 20, 493-509.

Ramaswami, A., \& Dreher, G. F. (2007). The benefits associated with workplace mentoring relationships. In T. D. Allen \& L. T. Eby (Eds.), Blackwell handbook of mentoring: A multiple perspectives approach (pp. 211-231). London: Blackwell.

Raudenbush, S. W., \& Bryk, A. S. (2002). Hierarchical linear models: Applications and data analysis methods (2nd ed.). Thousand Oaks, CA: Sage Publications.

Raudenbush, S. W., Bryk, A. S., \& Congdon, R. (2004). HLM 6 hierarchical linear and nonlinear modeling [computer software]. Lincolnwood, IL: Scientific Software International, Inc..

Rhodes, J. E. (2001). Youth mentoring in perspective. The Center Summer. Republished in the encyclopedia of informal education. Online: http://www.infed.org/learningmentors/youth mentoring in perspective.htm

Rhodes, J. E., \& Bogat, G. A. (Eds.). (2002). Youth mentoring [Special issue]. Journal of American Community of Psychology, 30.

Scandura, T. A., \& Schriesheim, C. A. (1994). Leader-member exchange and supervisor career mentoring as complementary constructs in leadership research. Academy of Management Journal, 37, 1588-1602.

Scandura, T. A., \& Williams, E. A. (2004). Mentoring and transformational leadership: The role of supervisory career mentoring. Journal of Vocational Behavior, 65, 448-468.

Schulz, S. F. (1995). The benefits of mentoring. In M. W. Galbraith \& N. H. Cohen (Eds.). Mentoring: New strategies and challenges (Vol. 66, pp. 57-68). San Francisco: Jossey-Bass Publishers.

Schwartz, S. H. (1992). Universals in the content and structure of values: Theoretical advances and empirical tests in 20 countries. In M. P. Zana (Ed.), Advances in experimental social psychology (pp. 323-349). New York: Academic Press.

Smith, P. B. (2006). When elephants fight, the grass gets trampled: The GLOBE and Hofstede projects. Journal of International Business Studies, 37, 915-921.

Sosik, J. J., \& Godshalk, V. M. (2000). Leadership styles, mentoring functions received, and job-related stress: A conceptual model and preliminary study. Journal of Organizational Behavior, 21, 365-390.

Sosik, J. J., Godshalk, V. M., \& Yammarino, F. J. (2004). Transformational leadership, learning goal orientation, and expectations for career success in mentor-protégé relationships: A multiple level of analysis paper. The Leadership Quarterly, 15, 241-261.

Triandis, H. C. (2003). Forty-five years of researching the culture and behavior link. In D. Tjosvold \& K. Leung (Eds.), Cross-cultural management: Foundations and future (pp. 11-27). Aldershot, Hants, England; Burlington, VT: Ashgate.

Trompenaars, F. (1994). Riding the waves of culture. Chicago, IL: Irwin Professional Publishing.

Underhill, C. M. (2006). The effectiveness of mentoring programs in corporate settings: A meta-analytical review of the literature. Journal of Vocational Behavior, 68(2), 292-307.

Van Velsor, E., Taylor, S., \& Leslie, J. B. (1993). An examination of the relationships among self-perception accuracy, self-awareness, gender, and leader effectiveness. Human Resource Management, 32(2-3), 249-263.

Viswesvaran, C., Ones, D. S., \& Schmidt, F. L. (1996). Comparative analysis of the reliability of job performance ratings. Journal of Applied Psychology, 81, 557-574.

Wanberg, C. R., Welsh, E. T., \& Hezlett, S. A. (2003). Mentoring research: A review and dynamic process model. In J. J. Martocchio \& G. R. Ferris (Eds.). Research in personnel and human resources management (Vol. 22, pp. 39-124). Oxford: Elsevier.

Wollack, S., Goodale, J. G., Wijting, J. P., \& Smith, P. C. (1971). Development of the survey of work values. Journal of Applied Psychology, 55, 331-338. 